\author{
Sheila Unger · David A. Paul · Michelle C. Nino \\ Charles P. McKay · Stephen Miller · Etienne Sochett \\ Nancy Braverman · Joe T. R. Clarke - David E. C. Cole \\ Andrea Superti-Furga
}

\title{
Mucolipidosis II presenting as severe neonatal hyperparathyroidism
}

Received: 25 August 2004/ Revised: 19 October 2004/ Accepted: 21 October 2004 / Published online: 3 December 2004

(C) Springer-Verlag 2004

\begin{abstract}
Mucolipidosis II (ML II or I-cell disease) (OMIM 252500) is an autosomal recessive lysosomal enzyme targeting disorder that usually presents between 6 and 12 months of age with a clinical phenotype resembling Hurler syndrome and a radiological picture of dysostosis multiplex. When ML II is severe enough to be detected in the newborn period, the radiological changes have been described as similar to hyperparathyroidism or rickets. The biological basis of these findings has not been explored and few biochemical measurements have been recorded. We describe three unrelated infants with ML II who had radiological features of intrauterine hyperparathyroidism and biochemical findings consistent with severe secondary neonatal hyperparathyroidism (marked elevation of serum parathyroid hormone and alkaline phosphatase levels). The vitamin D metabolites were not substantially different from normal and repeatedly normal calcium concentrations excluded vitamin D deficiency rickets and neonatal severe hyperparathyroidism secondary to calcium-sensing receptor gene mutations (OMIM
\end{abstract}

Some material from this paper was presented at the 6th International Skeletal Dysplasia Conference in Warrenton, Virginia, August 22, 2003.

S. Unger $(\bowtie) \cdot$ J. T. R. Clarke · D. E. C. Cole

Division of Clinical and Metabolic Genetics,

The Hospital for Sick Children, Toronto, Canada

E-mail: Sheila.Unger@hospvd.ch

D. A. Paul

Department of Pediatrics, Section of Neonatology,

Christiana Care Health System, Newark, USA

D. A. Paul · C. P. McKay

Department of Pediatrics, Thomas Jefferson University, Philadelphia, USA

M. C. Nino $\cdot$ N. Braverman

McKusick-Nathans Institute of Genetic Medicine,

Johns Hopkins University School of Medicine,

Baltimore, USA

C. P. McKay

Department of Pediatrics, Section of Nephrology, DuPont Hospital for Children, Wilmington, USA
239200). The pathogenesis of severe hyperparathyroidism in the fetus and newborn with ML II is unexplained. We hypothesize that the enzyme targeting defect of ML II interferes with transplacental calcium transport leading to a calcium starved fetus and activation of the parathyroid response to maintain extracellular calcium concentrations within the normal range. Conclusion: Newborns with mucolipidosis II can present with radiological and biochemical signs of hyperparathyroidism. Awareness of this phenomenon may help in avoiding diagnostic pitfalls and establishing a proper diagnosis and therapy.

Keywords Hyperparathyroidism - I-cell disease · Mucolipidosis II · Neonatal

Abbreviations ALP: alkaline phosphatase - CASR: calcium-sensing receptor $\cdot 1,25 \mathrm{D}$ :

1,25-dihydroxyvitamin D - ML II: mucolipidosis II ·

NSHPT: neonatal severe

hyperparathyroidism - 25OHD: 25-hydroxyvitamin D ·

S. Miller

Department of Diagnostic Imaging,

The Hospital for Sick Children, Toronto, Canada

E. Sochett

Department of Endocrinology,

The Hospital for Sick Children, Toronto, Canada

D. E. C. Cole

Departments of Laboratory Medicine

and Pathobiology and Medicine, University of Toronto,

Toronto, Canada

D. E. C. Cole

Department of Clinical Pathology, Sunnybrook

and Women's College Health Sciences Centre, Toronto, Canada

A. Superti-Furga

Department of Pediatrics, Division of Molecular Paediatrics,

University of Lausanne, Lausanne, Switzerland

Present address: S. Unger

Department of Medical Genetics,

Centre Hospitalier Universitaire Vaudois,

1011 Lausanne, Switzerland 
PTH: parathyroid hormone $\cdot$ PTHrP: parathyroid hormone-related peptide

\section{Introduction}

Mucolipidosis II (ML II), or I-cell disease (OMIM 252500), is a rare storage disorder resulting from a defect in the localisation of lysosomal enzymes into the lysosomes. Normally, nascent lysosomal enzymes in the endoplasmic reticulum are recognised by their mannose6-phosphate residues in the N-linked carbohydrate sidechains, directing them to the lysosomal compartment. In ML II, the enzyme catalysing the addition of mannose6-phosphate to the polyantennary carbohydrate sidechains is deficient, leading to increased release of enzyme into the extracellular medium at the expense of the lysosomal compartment [27]. ML II was first recognised as a distinct entity in 1967 and was described as a Hurler-like disorder [16]. However, it has a more severe phenotype than Hurler disease with marked skeletal dysplasia, significant psychomotor retardation, and death within the first decade of life [17,20]. The diagnosis of ML II is most often made in the second half of the 1st year of life as the facial features coarsen, the growth failure becomes more evident, and developmental concerns are noted [20]. The diagnosis is established by detection of multiple elevations in serum lysosomal enzyme activities and/or low activity in fibroblasts. Under light microscopy, characteristic inclusions are observed in cultured fibroblasts. Following the diagnosis, nonspecific neonatal features of the disease are often recognised in retrospect. These include congenital hip dislocation, club foot, inguinal hernia, gingival hypertrophy and small birth weight or birth length [3,17].

In the first description of an ML II patient cohort, it was noted that striking periosteal new bone formation ("cloaking" of the long bones) may be seen on newborn $\mathrm{X}$-ray films, but it gradually resolves. The aetiology of this early disturbance in bone mineral balance was not further explored [17]. Several authors have since documented an "early stage" of bone changes in ML II that precedes the development of typical dysostosis multiplex [7, 15, 22,32]. These abnormalities have been variously described as sub-periosteal resorption, rickets-like, or cloaking. The skeleton is osteopenic and some infants with frank fractures were initially diagnosed as lethal osteogenesis imperfecta [3,32]. In 1989, Pazzaglia et al. described a child with ML II who died at 5 months of age with biochemical evidence of hyperparathyroidism (elevated parathyroid hormone (PTH) and elevated alkaline phosphatase (ALP) but low-to-normal serum calcium and phosphate with increased urinary phosphate). Histological examination of bone at autopsy revealed changes consistent with hyperparathyroidism [24]. Further evidence that the disease is associated with a true disturbance in mineral metabolism comes from the report of a child with ML II who was detected as having an osteopenic bone dysplasia in utero and subsequently received vitamin $\mathrm{D}$ supplementation for the 1 st year of life [22]. In that child, the radiological features of metabolic bone disease resolved more quickly than in another infant who was untreated. The authors speculated that ML II perturbs vitamin D metabolism in the maternal environment [22].

We present three further cases of ML II complicated by prenatal onset hyperparathyrodism. Our observations suggest that the hyperparathyroidism is secondary to a defect in fetal importation of calcium.

\section{Case reports}

\section{Case 1}

This child was born at 35.5 weeks gestation following an uneventful pregnancy. The mother was a 29 -year-old G3 P1 SA (spontaneous abortion)1 woman who had one healthy daughter. A single antenatal ultrasound done at 18 weeks was reportedly normal. At birth, the proband was noted to be small for gestational age with a birth weight of $1.99 \mathrm{~kg}$ (10th percentile), birth length of approximately $43 \mathrm{~cm}$ (10th percentile) and a head circumference of $30 \mathrm{~cm}$ (10th percentile). Her Apgar scores were 5 at $1 \mathrm{~min}$ and 8 at $5 \mathrm{~min}$. She had moderate respiratory distress requiring supplemental oxygen but was not intubated, and a chest X-ray film revealed irregular and osteopenic ribs. The child was subsequently referred to the Hospital for Sick Children for further evaluation. The infant appeared wasted and unwell and the gums were hypertrophied (Fig. 1). Although the limbs were generally proportionate, the left leg was bent and foreshortened. The ribs were easily palpable and nodular. The X-ray films showed dramatic osteopenia and shortening of the long bones. There was an appearance of "bone cloaked in bone" and expanded metaphyses (Fig. 2).

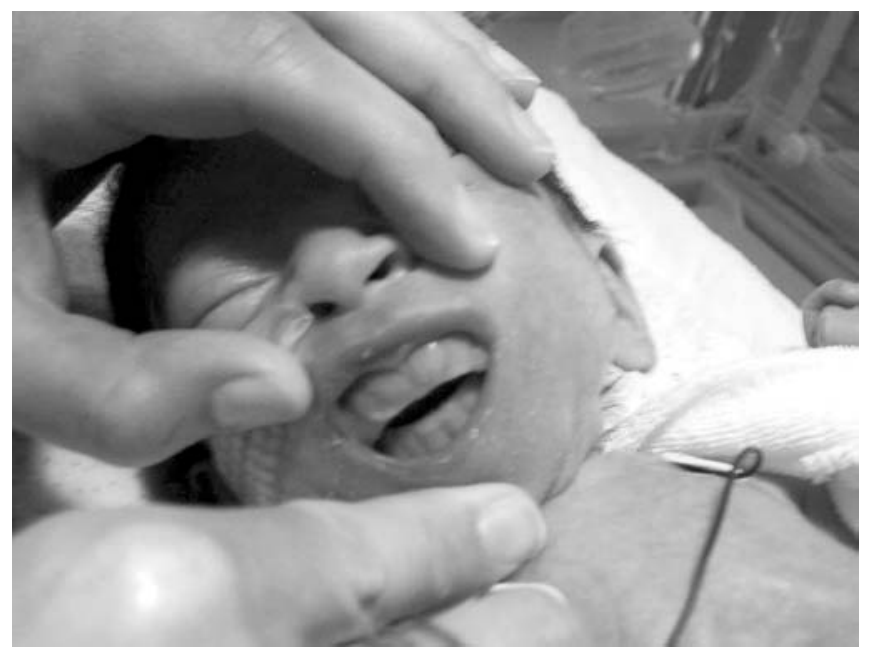

Fig. 1 Photograph of case 1 taken on day 2 and shows the hypertrophied gums typical of ML II 


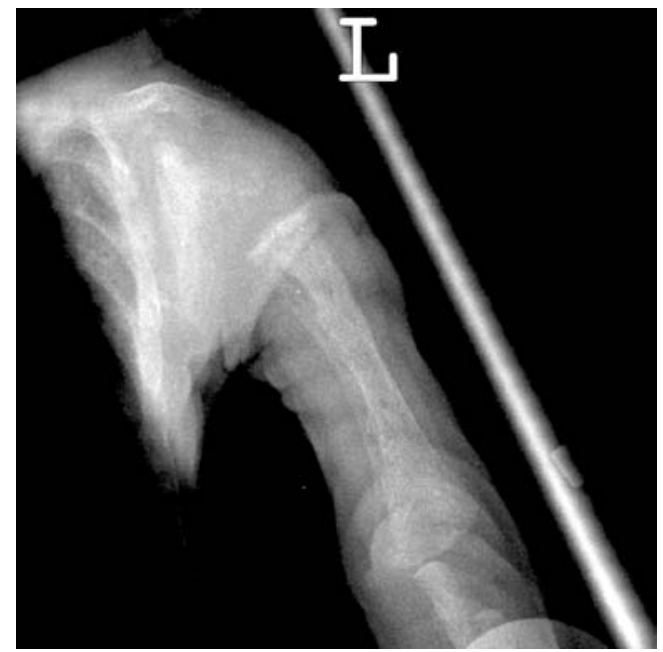

Fig. 2 X-ray film of the left humerus of case 1 on day 4 showing osteopenia and cloaking as well as expansion at the proximal metaphysis. Note also the poor cortical delineation of the lateral aspect of the scapula
On day 2 of life, the total serum calcium was $2.24 \mathrm{mmol} / 1$ (reference range $2.12-2.62 \mathrm{mmol} / \mathrm{l}$ ) and the ionised calcium $1.16 \mathrm{mmol} / \mathrm{l}$ (reference range $1.14-1.29 \mathrm{mmol} / \mathrm{l})$. On day 4 of life, the phosphate was $1.12 \mathrm{mmol} / 1$ (reference range $1.30-2.20 \mathrm{mmol} / \mathrm{l}$ ), and the ALP was $711 \mathrm{U} / 1$ (reference range 185-555 IU/1). On further investigation, the serum PTH was also elevated, measuring $471 \mathrm{ng} / 1$ on day 10 of life (reference range $10-65 \mathrm{ng} / \mathrm{l})$ and peaking at $1178 \mathrm{ng} / \mathrm{l}$ at 2 weeks of age. On day 10, serum 25-hydroxyvitamin D (25OHD) was $18 \mathrm{nmol} / 1$ (reference range $25-90 \mathrm{nmol} / \mathrm{l}$ ) and 1,25-dihydroxyvitamin D $(1,25 \mathrm{D})$ was $100 \mathrm{pmol} / 1$ (reference range $40-140 \mathrm{pmol} / \mathrm{l})$. In a maternal blood sample, the following serum parameters were normal: calcium (2.16 mmol/l), phosphate (1.42 mmol/l), ALP (131 IU/l; reference range $25-100 \mathrm{IU} / 1$ in adults), PTH (52 ng/l), 25OHD (47 nmol/l) and 1,25D (51 pmol/l).

Over the course of the first 3 months of life, she was treated with vitamin $\mathrm{D}$ and calcium supplementation. Her metabolic bone disease resolved both biochemically (Fig. 3) and radiologically (Fig. 4). The PTH normalised by 1 month of age and the ALP levels followed a similar
Fig. 3 Time course of vitamin $\mathrm{D}$ treatment and changing calcium metabolism in case 1 . Shown on this graph are serum PTH, phosphate, and total serum calcium values for the first few months of life. At the time vitamin $\mathrm{D}$ and calcium supplements were started (day $12)$, serum $25(\mathrm{OH}) \mathrm{D}$ and $1,25(\mathrm{OH}) 2 \mathrm{D}$ concentrations (top of figure) were consistent with reported reference values (mean $\pm \mathrm{SD}$ ) for preterm newborns $(33 \pm 11 \mathrm{nmol} / 1$ and $56 \pm 33 \mathrm{pmol} /$, respectively) [29]. Phosphate supplements were started on day 32 , after the level dropped to 0.77 . Urine studies done on day 25 had shown that there was no urinary loss of phosphate, glucose, amino acids or protein
25(OH)D

$1,25(\mathrm{OH})_{2} \mathrm{D}$

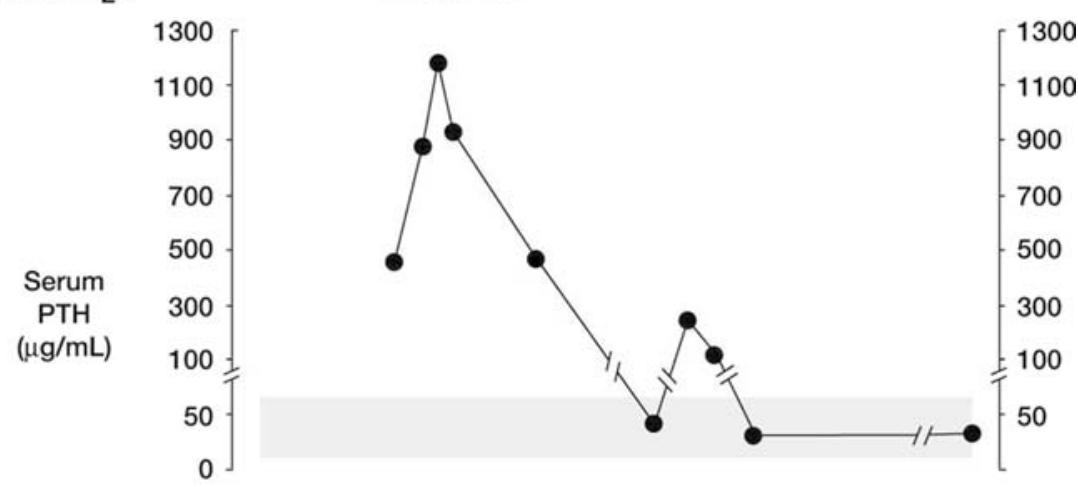

Serum

phosphate

(mmol/L)

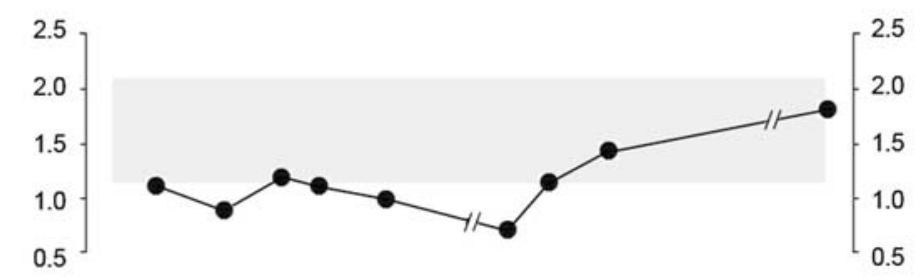

Total
serum
calcium
$(\mathrm{mmol} / \mathrm{L})$

Calcitriol

$(\mu \mathrm{g} /$ day)

Vitamin D

(IU/day)
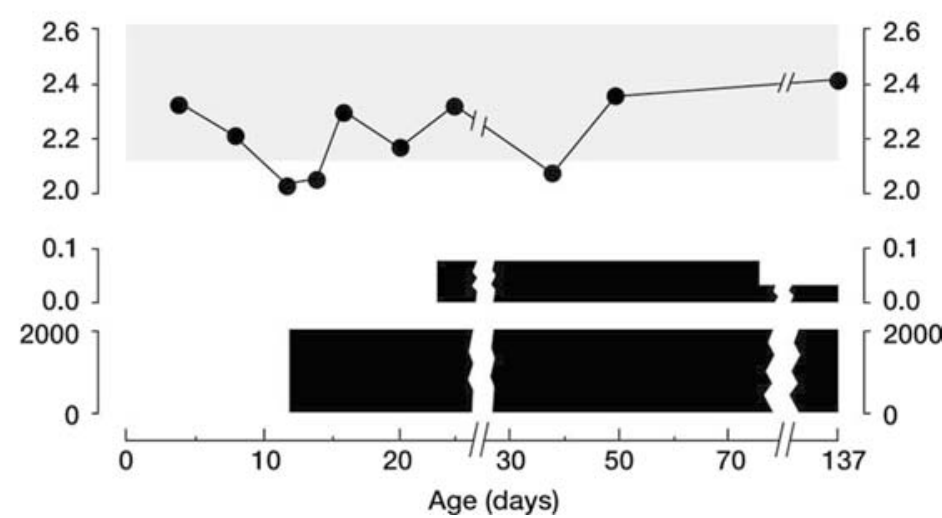

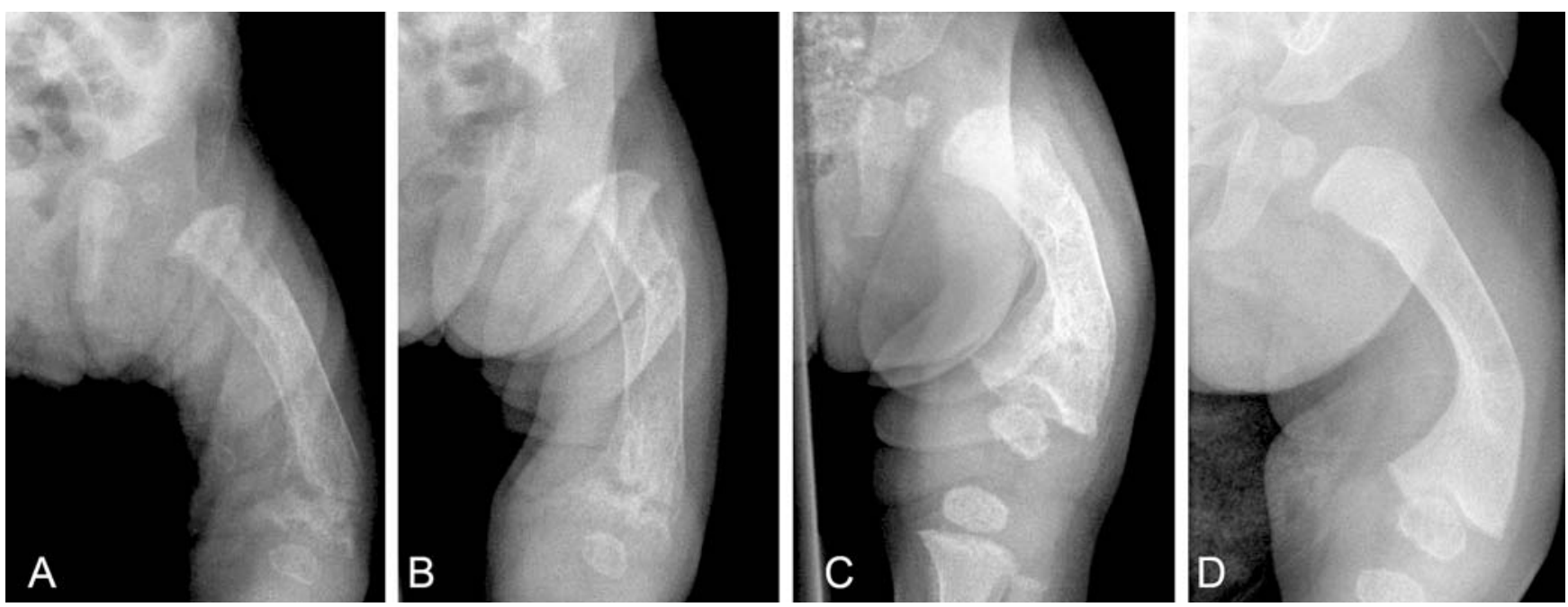

Fig. 4 X-ray films of the left femur demonstrating the changes over the first 4 months of life in case 1. A 4 days: the femur is osteopenic and bent with a sleeve of calcification around an inner bone. The area proximal to the distal femoral metaphysis appears unossified and the metaphysis itself is frayed and expanded, as is the proximal tibial metaphysis. B 2 weeks: the bend in the femur is even more acute at this age with worsening of the metaphyseal changes. C 6 weeks: with introduction of vitamin D therapy, the osteopenia has lessened, the metaphysis is less irregular, and periosteal cloaking is resolving. D 4 months: the metaphyseal changes have resolved and the texture of the bone is improved. A degree of diaphyseal expansion remains, as is typical for severe dysostosis multiplex in ML II

but delayed course. However, the child continued to be unwell and her facial features coarsened. The diagnosis of ML II was confirmed by assay of enzymes in serum: arylsulfatase A $114 \mathrm{nmol} / \mathrm{h}$ per mg of protein (reference range $21-72 \mathrm{nmol} / \mathrm{h} / \mathrm{mg}$ protein) and total hexosaminidase $64180 \mathrm{nmol} / \mathrm{h}$ per $\mathrm{ml}$ (reference range 2350$2450 \mathrm{nmol} / \mathrm{h} / \mathrm{ml}$ ). The radiological changes, in particular the ribs, evolved into typical dysostosis multiplex (Fig. 5). She suffered recurrent aspiration pneumonias and died at 5 months of age.

\section{Case 2}

This patient was born at 36.5 weeks to an 18 -year-old G1P0 mother. The parents were first cousins of Pakistani origin. The pregnancy had been complicated by oligohydramnios and poor growth. Following the onset of preterm labour, the child was delivered by caesarean section for breech presentation. He was noted to be small for gestational age with a birth weight of $2.1 \mathrm{~kg}$ ( $<10$ th percentile), head circumference of $31.5 \mathrm{~cm}$ (10th percentile) and a birth length of $43 \mathrm{~cm}(<10$ th percentile). The patient also had bilateral inguinal hernias and club feet. He had poor respiratory effort at birth and briefly required positive pressure ventilation. His Apgar scores were 5 at $5 \mathrm{~min}$ and 9 at $10 \mathrm{~min}$. He was transferred to Johns Hopkins Hospital at 1 week of life for further investigation and treatment.

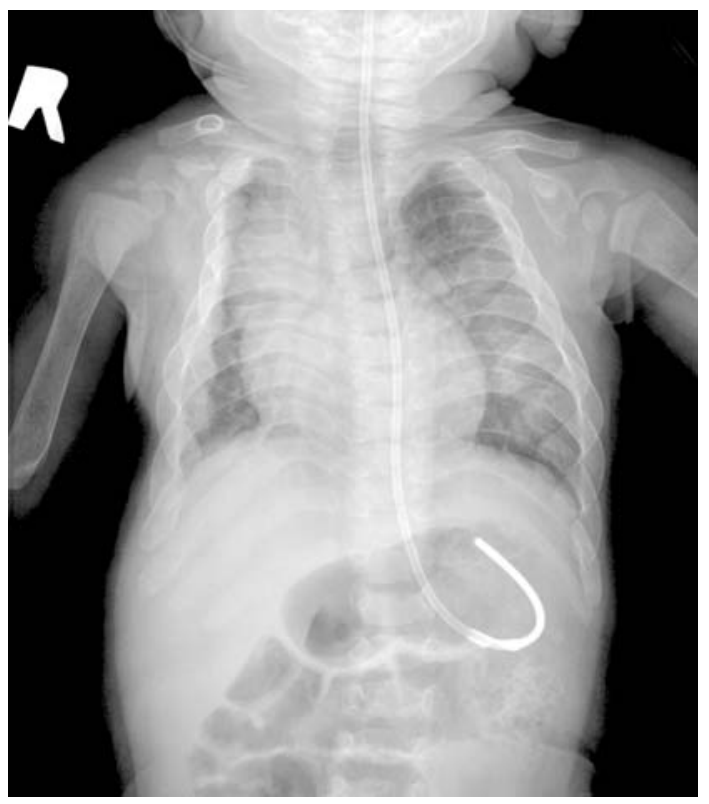

Fig. 5 PA film of the chest (case 1) at 4 months shows the greatly expanded ribs, typical of ML II

Skeletal survey at 2 weeks of age revealed generalised osteopenia with some bones being barely visible. There was fraying and expansion of all metaphyses and stippling was noted in both tarsal areas (Fig. 6). A calcium level done that day was normal at $2.38 \mathrm{mmol} / 1$ as was the phosphate $(1.26 \mathrm{mmol} / \mathrm{l})$. The ALP was elevated at $1350 \mathrm{IU} / 1$ and the PTH level was measured 3 days later at $455 \mathrm{ng} / \mathrm{l}$. The $25 \mathrm{OHD}$ level was slightly low at $9 \mathrm{nmol} / 1$ while the $1,25 \mathrm{D}$ was normal $(60 \mathrm{pmol} / \mathrm{l})$. The ALP level rose steadily (from $1350 \mathrm{IU} / 1$ to $2593 \mathrm{IU} / \mathrm{l}$ ) and vitamin D therapy (3600 U ergocalciferol/day) was initiated at 1 month. At that time, his calcium and phosphate levels remained normal $(2.45 \mathrm{mmol} / 1$ and $1.55 \mathrm{mmol} / \mathrm{l}$ respectively). Within a week of vitamin D therapy, the PTH level had begun to drop and the ALP level started decreasing after 2 weeks of therapy. The last measurement of ALP at 4 months of age was 1881 IU/1. 
Fig. 6 X-ray film of the distal tibia and fibula of case 2 demonstrating metaphyseal expansion and fraying typical of hyperparathyroidism as well as the bilateral tarsal stippling which is frequently seen in $\mathrm{ML}$ II $[1,7,32]$

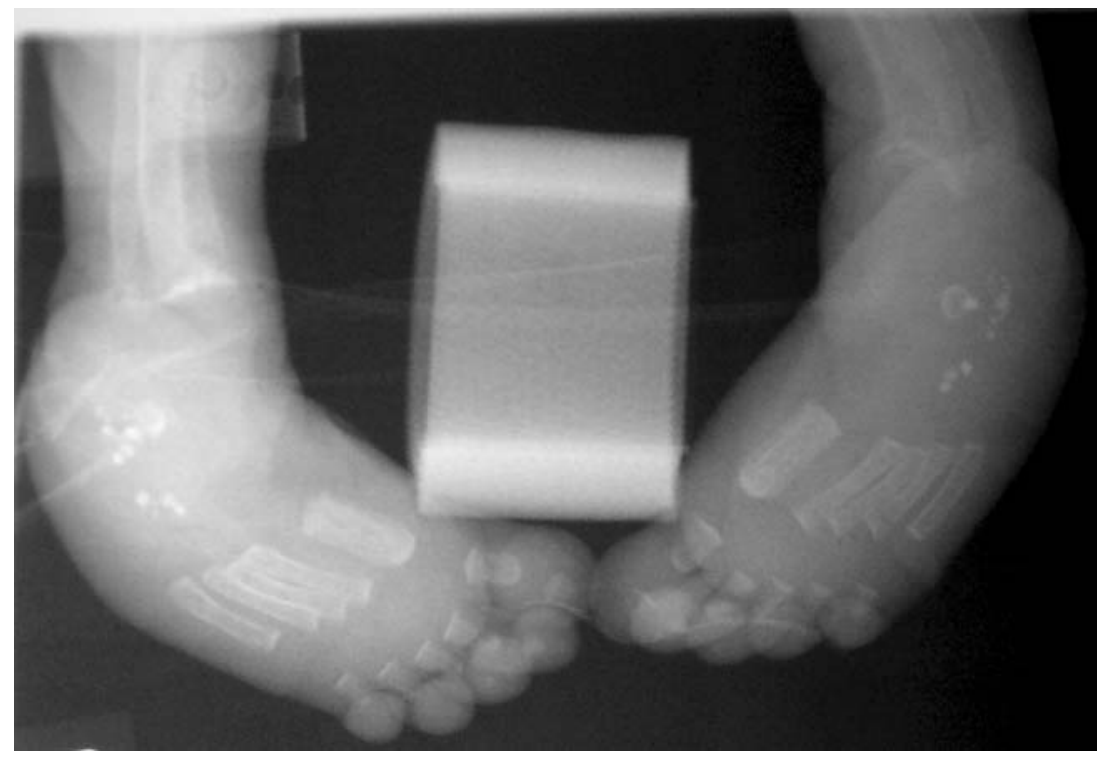

$\mathrm{X}$-ray films at that age showed some resolution of the osteopenia but periosteal reaction was still present. Unfortunately, the child was lost to further follow-up when the family moved back to Pakistan.

The diagnosis of ML II had been confirmed at 2 weeks of age by assay of enzymes in serum: arylsulfatase A $1767 \mathrm{nmol} / \mathrm{h}$ per $\mathrm{ml}(0 \mathrm{nmol} / \mathrm{h} / \mathrm{ml}$ in control $)$ and total hexosaminidase $23880 \mathrm{nmol} / \mathrm{h}$ per ml. A skin biopsy was done and assay of enzyme activities in fibroblasts showed a drastic reduction in substrate hydrolysed compared to controls and characteristic inclusions were seen on light microscopy, further confirming the diagnosis of ML II.

\section{Case 3}

The patient was born to a 28 -year-old G4P3L1 mother. The parents were non-consanguineous and of Hispanic descent. The parents previously had one infant who died in rural Mexico after being born at 24 weeks gestation and another infant who died in Mexico at 9 months of age from "brittle bone" disease. This fourth child of the couple was born by caesarean section at 29 weeks gestation because of fetal bradycardia. The Apgar scores were 6 at $1 \mathrm{~min}$ and 7 at $5 \mathrm{~min}$. Intubation, along with surfactant administration, was required for treatment of respiratory distress and the child remained intubated for the 1st month of life. The admitting physical examination revealed a birth weight of $941 \mathrm{~g}$ (3rd percentile) and the head circumference was $25.5 \mathrm{~cm}(<50$ th percentile).

On admission, a chest X-ray film showed a granular pattern to the lung parenchyma consistent with respiratory distress syndrome. Skeletal X-ray films showed generalised osteopenia. The periosteal cloaking was most dramatic in the humeri producing an almost bone within bone appearance and cloaking was also evident in both femurs and the forearms (Fig. 7). In addition, 11 paired ribs were noted and there was coccygeal stippling.

On the 1st day of life, serum phosphate was $2.2 \mathrm{mmol} / \mathrm{l}$, total calcium was $1.9 \mathrm{mmol} / \mathrm{l}$, and the ALP was $498 \mathrm{IU} / 1$. A renal ultrasound was normal with no evidence of nephrocalcinosis. On day 26, the 25OHD was $25.0 \mathrm{nmol} / 1$ and $1,25 \mathrm{D}$ was $149 \mathrm{pmol} / \mathrm{l}$. A PTH level was markedly elevated at $651 \mathrm{ng} / 1$ and at 2 months remained elevated $(358 \mathrm{ng} / \mathrm{l})$. ALP continued to rise and was $1015 \mathrm{IU} / 1$ at 1 month. At this time, the serum calcium and phosphate remained in the normal range at $2.2 \mathrm{mmol} / 1$ and $1.9 \mathrm{mmol} / 1$ respectively. Both parents were evaluated when the baby was 6 weeks old and their
Fig. 7 X-ray film of the humeri and upper chest of case 3 at 8 days. Both humeri have a cloaked appearance (bone within a sleeve of bone) and the ribs are osteopenic and somewhat broadened

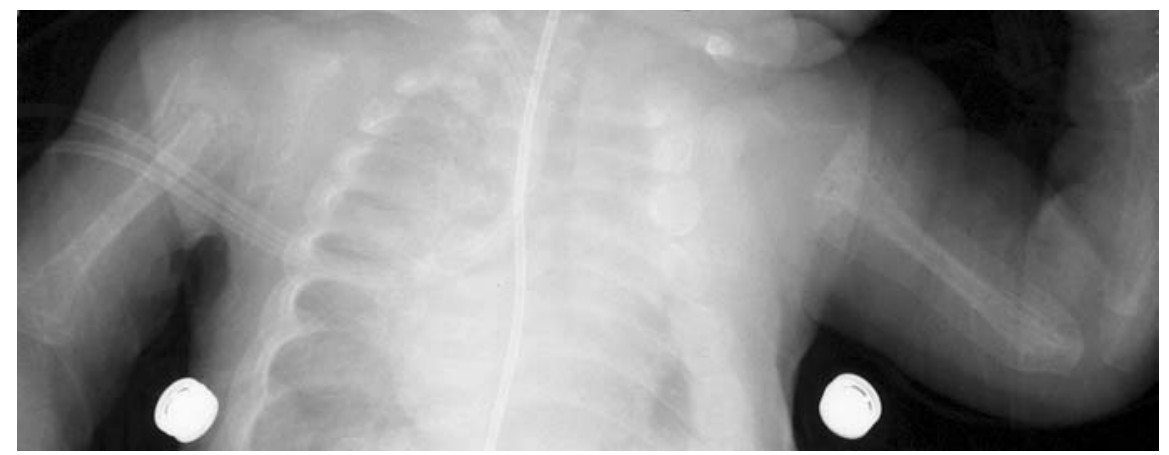


PTH levels were normal. The mother's calcium was $2.3 \mathrm{mmol} / 1$ and phosphate $1.1 \mathrm{mmol} / \mathrm{l}$. The father's calcium was $2.3 \mathrm{mmol} / \mathrm{l}$ and phosphate was $1.6 \mathrm{mmol} / \mathrm{l}$.

The infant developed dysmorphic facial features with marked gingival hypertrophy and enzyme studies in cultured fibroblasts confirmed the diagnosis of ML II. Alpha-mannosidase activity was $0.65 \mathrm{nmol}$ substrate hydrolyzed/h per mg protein (control $38.4 \mathrm{nmol} / \mathrm{h} / \mathrm{mg}$ ), beta-galactosidase activity was $2.2 \mathrm{nmol}$ substrate hydrolysed/h per mg protein (control $254 \mathrm{nmol} / \mathrm{h} / \mathrm{mg}$ ), and beta-hexosaminidase activity was $199 \mathrm{nmol}$ substrate hydrolysed/h per mg protein (control $3094 \mathrm{nmol} / \mathrm{h} / \mathrm{mg}$ ). In addition, cultured cells were engorged with large dense lysosomes consistent with ML II.

The infant was discharged home at 3.5 months requiring supplemental oxygen and gastrostomy tube feedings. He was not treated with vitamin D or calcium supplements. At 4 months, the calcium was $2.3 \mathrm{mmol} / 1$, phosphate was $2.0 \mathrm{mmol} / 1$ and ALP was further elevated at $1289 \mathrm{IU} / 1$ while intact PTH was $103 \mathrm{ng} / 1$. At 16 months, a repeat ALP was normal $(160 \mathrm{IU} / \mathrm{l})$ and the rib fractures had healed. Follow-up at 20 months showed that the radiological features of hyperparathyroidism had resolved as had the biochemical features (ALP $503 \mathrm{IU} / 1$, PTH $58 \mathrm{ng} / \mathrm{l}$, total calcium $2.3 \mathrm{mmol} / \mathrm{l}$ ).

\section{Discussion}

Review of the literature shows there is a subset of patients with ML II who present in the neonatal period with features of "metabolic" bone disease rather than with signs of dysostosis multiplex $[1,3,4,5,7,9,15,17$, $21,23,31,32,34]$. Indeed, the presenting feature of our patients was bone disease with increased serum PTH and ALP activity, but normal serum calcium concentrations. This 'secondary' hyperparathyroidism resolved spontaneously or with supplemental vitamin D and calcium. All three children developed typical clinical and radiological features of ML II later in the course, and only then was the confirmation of the underlying disorder straightforward.

While several authors have noted a hyperparathyroidlike or rickets-like phenotype at birth in ML II, there have been limited investigations of this early bone disease, perhaps because of the lack of hypocalcaemia and the lethal nature of ML II. In some cases, an initial diagnosis of osteogenesis imperfecta is suspected because of severe osteopenia, fractures and long bone deformity $[15,17,22$, 23,31]. In a review of the radiology in 12 patients, Pazzaglia et al. identified two groups [23]. The first consisted of seven patients presenting at birth or in the early neonatal period with radiological features of hyperparathyroidism. Four of their cases had elevated ALP and histological examination of the bone, available in two cases, was consistent with rickets and/or hyperparathyroidism $[23,24]$. In their series, the authors noted that the neonatal presentation was associated with an unfavourable course and early lethality. Review of other cases with perinatal metabolic bone disease supports this conclusion, as most infants with neonatal manifestations of ML II have died before the 2nd year of life [5, 15, 21, 32,34], rather than the more usual life expectancy of 3 to 8 years $[17,20]$. After birth, the extracellular calcium concentration is meticulously controlled by a G-protein coupled calcium-sensing receptor (CASR) in the parathyroid gland $[8,25]$. Heterozygosity for an inactivating mutation of the $C A S R$ gene causes hypocalciuric hypercalcaemia in both mice and men (OMIM 145980) [8,25] and in some instances (e.g., a mutation-carrying fetus in a normocalcemic mother) can lead to neonatal severe hyperparathyroidism (NSPHT) (OMIM 239200) [2]. NSHPT can also be caused by homozygous inactivating mutations of the CASR [6]. The radiological phenotype of NSHPT is very similar to that seen in severe neonatal ML II; however, the two disorders are readily distinguishable at a biochemical level, because the elevated PTH concentrations in NSHPT are matched by reactively high serum calcium levels [2,6]. In contrast, the extracellular calcium concentrations are normal in ML II cases with elevated PTH, supporting the notion that coupling between calcium and PTH is unaffected, and that the parathyroid gland, through its intact CASRs, is responding to severe prenatal calcium deficiency by secreting PTH in order to maintain a normal extracellular calcium concentration. This would explain the finding that the metabolic bone disease resolves postnatally either spontaneously or perhaps more rapidly following treatment with vitamin D and calcium $[22,28]$.

Evidence from mouse models has shown that PTH has a role in fetal calcium homeostasis, but it is shared with its oncofetal homologue, parathyroid hormone-related peptide (PTHrP) $[12,14]$. In utero, active calcium transport across the placenta accelerates in the third trimester as the growing skeleton calcifies and the fetus has higher serum calcium than the mother, despite efficient transfer from the extracellular compartment into mineralising bone [11]. Homozygous Hoxa-3 null mice are aparathyroid and have undetectable levels of PTH. These mice are hypocalcaemic and hyperphosphataemic but have a normal rate of placental calcium transfer [13]. Interestingly, fetal mice who are homozygous null for the PTHrP gene are hypocalcaemic and unable to maintain the maternal-fetal calcium gradient, due to reduced transplacental calcium transport [11]. These mice have a skeletal dysplasia with moderately shortened long bones in utero and they do not survive the neonatal period [10]. The model to account for the observations in fetal mice with different gene deletions, is that fetal CASR regulates serum calcium via PTH levels, while a different receptor in the placenta is likely responsible for coupling the endocrine signal of fetal PTHrP to the trans-placental transport process $[13,14]$.

Deficient transplacental calcium transport can lead to hyperparathyroidism in the fetus; an infant born to a mother with idiopathic hypoparathyroidism and frequent hypocalcaemia had low normal calcium but markedly increased PTH with demineralisation of the 
skeleton and metaphyseal changes [18]. In MLII, the placenta is affected [26], and histological examination shows generalised vacuolisation of the cytoplasm (the 'inclusions' of I-cell disease) in the syncytiotrophoblastic layer where active transplacental transport is regulated $[1,26]$. It is reasonable, therefore, to speculate that the inclusion process interferes with appropriate localisation or action of PTHrP and/or its receptor(s) and diminishes placental calcium transfer with concordant increase in PTH secretion to maintain extracellular calcium at the expense of the skeleton.

Recognising ML II as a possible cause of neonatal hyperparathyroidism is important because although the osteopenia may improve, the overall prognosis is determined by the underlying lysosomal disorder. In the newborn, the radiological features of hyperparathyroidism may be prominent and obscure the more subtle signs of ML II. In 1993, Shohat et al. [30], reported an infant born at 28 weeks who died at 30 min of age and described her condition as a "new epiphyseal stippling syndrome with osteoclastic hyperplasia" and suggested the name Pacman dysplasia. Since that time a further three fetuses have been reported as having Pacman dysplasia (OMIM 167220) $[19,33]$. While it was recognised that the radiological features (including fetal stippling) were similar to ML II, it was felt that the histology was not consistent with that disorder since it consisted of excessive bone resorption with numerous osteoclasts including giant multinucleated ones [19, 30,33]. However, that histology is entirely consistent with hyperparathyroidism and in the light of our observations, it seems most likely that Pacman dysplasia is actually fetal/neonatal MLII with secondary hyperparathyroidism. Indeed, after we had suggested this hypothesis at the 2003 ISDS meeting, a family whose first fetus had been diagnosed with Pacman dysplasia [19] had a second child who had ML II [29], confirming this hypothesis.

ML II can present in the neonatal period with severe secondary hyperparathyroidism, possibly as a result of impaired transplacental calcium transport. While ML II remains a rare recessive condition, careful observation of the phenotype may provide us with insights into the normal process of fetal accretion of calcium and skeletal mineralisation. Clinicians should be aware that when a fetus or infant presents with shortened and bowed limbs and osteopenia, hyperparathyroidism secondary to severe ML II is a diagnostic possibility.

Acknowledgements We would like to thank the families for their gracious participation in this project. David Cole is supported in part by grants from NSERC and Dairy Farmers of Canada. Andrea Superti-Furga is supported by the Swiss National Foundation (grant no. 3100A0-100485).

\section{References}

1. Babcock DS, Bove KE, Hug G, Dignan PSJ, Soukup S, Warren NS (1986) Fetal mucolipidosis II (I-cell disease): radiologic and pathologic correlation. Pediatr Radiol 16: 32-39
2. Bai M, Pearce SHS, Kifor O, Trivedi S, Stauffer UG, Thakker RV, Br EM, Steinmann B (1997) In vivo and in vitro characterization of neonatal hyperparathyroidism resulting from a de novo, heterozygous mutation in the $\mathrm{Ca} 2+$-sensing receptor gene: normal maternal calcium homeostasis as a cause of secondary hyperparathyroidism in familial benign hypocalciuric hypercalcemia. J Clin Invest 99: 88-96

3. Beck M, Barone R, Hoffmann R, Kratzer W, Rakowsky T, Nigro F, Fiumara A (1995) Inter- and intrafamilial variability in mucolipidosis II (I-cell disease). Clin Genet 47: 191-199

4. Bocca G, Noordam C, Wevers RA, de Jong JGN, van der Meer W, de Keijzer MH, Korver CRW, Smeitink JAM (2000) I-cell disease presenting with severe hypophosphatemia and cardiomyopathy. Neuropediatrics 31: 49-50

5. Cipolloni C, Boldrini A, Donti E, Maiorana A, Coppa GV (1980) Neonatal mucolipidosis II (I-cell disease): clinical, radiological and biochemical studies in a case. Helv Paediatr Acta 35: 85-95

6. Cole DEC, Janici N, Salisbury SR, Hendy GN (1997) Neonatal severe hyperparathyroidism, secondary hyperparathyroidism, and familial hypocalciuric hypercalcemia: multiple different phenotypes associated with inactivating Alu insertion mutation of the calcium-sensing receptor gene. Am J Med Genet 71: 202-210

7. Herman TE, McAlister WH (1996) Neonatal mucolipidosis II (I-cell disease) with disharmonic epiphyseal ossification and butterfly vertebral body. J Perinatol 16: 400-402

8. Ho C, Conner DA, Pollak MR, Ladd DJ, Kifor O, Warren HB, Brown EM, Seidman JG, Seidman CE (1995) A mouse model of human familial hypocalciuric hypercalcemia and neonatal severe hyperparathyroidism. Nat Genet 11: 389 394

9. Hochman JA, Treem WR, Dougherty F, Bentley RC (2001) Mucolipidosis II (I-cell disease) presenting as neonatal cholestasis. J Inherit Metab Dis 24: 603-604

10. Karaplis AC, Luz A, Glowacki J, Bronson RT, Tybulewicz VL, Kronenberg HM, Mulligan RC (1994) Lethal skeletal dysplasia from targeted disruption of the parathyroid hormone-related peptide gene. Genes Dev 8: 277-289

11. Kovacs CS, Lanske B, Hunzelman JL, Guo J, Karaplis AC, Kronenberg HM (1996) Parathyroid hormone-related peptide (PTHrP) regulates fetal-placental calcium transport through a receptor distinct from the PTH/PTHrP receptor. Proc Natl Acad Sci USA 93: 15233-15238

12. Kovacs CS, Ho-Pao CL, Hunzelman JL, Lanske B, Fox J, Seidman JG, Seidman CE, Kronenberg HM (1998) Regulation of murine fetal-placental calcium metabolism by the calciumsensing receptor. J Clin Invest 101: 2812-2820

13. Kovacs CS, Manley NR, Moseley JM, Martin TJ, Kronenberg HM (2001) Fetal parathyroids are not required to maintain placental calcium transport. J Clin Invest 107: 1007-1015

14. Kovacs CS, Chafe LL, Fudge NJ, Friel JK, Manley NR (2001) PTH regulates fetal blood calcium and skeletal mineralization independently of PTHrP. Endocrinology 142: 4983-4993

15. Lemaitre L, Remy J, Farriaux JP, Dhondt JL, Walbaum R (1978) Radiological signs of mucolipidosis II or I-cell disease. Pediatr Radiol 7: 97-105

16. Leroy JG, Demars RI (1967) Mutant enzymatic and cytological phenotypes in cultured human fibroblasts. Science 157: 804-806

17. Leroy JG, Spranger JW, Feingold M, Opitz JM, Crocker AC (1971) I-cell disease: a clinical picture. J Pediatr 79: 360-365

18. Loughead JL, Mughal Z, Mimouni F, Tsang RC, Oestreich AE (1990) Spectrum and natural history of congenital hyperparathyroidism secondary to maternal hypocalcemia. Am J Perinatol 7: 350-355

19. Miller SF, Proud VK, Werner AL, Field FM, Wilcox WF, Lachman RS, Rimoin DL (2003) Pacman dysplasia :a lethal skeletal dysplasia with variable radiographic features. Pediatr Radiol 33: 256-260

20. Okada S, Owada M, Sakiyama T, Yutaka T, Ogawa M (1985) I-cell disease: clinical studies of 21 Japanese cases. Clin Genet 28: $207-215$ 
21. Patriquin HB, Kaplan P, Kind HP, Giedion A (1977) Neonatal mucolipidosis II (I-cell disease): clinical and radiologic features in three cases. Am J Roentgenol 129: 37-43

22. Pazzaglia UE, Beluffi G, Danesino C, Frediani PV, Pagani G, Zatti G (1989) Neonatal mucolipidosis II. The spontaneous evolution of early bone lesions and the effect of vitamin D treatment. Pediatr Radiol 20: 80-84

23. Pazzaglia UE, Beluffi Campbell JB, Bianchi E, Colavita N, Diard F, Gugliantini P, Hirche U, Kozlowski K, Marchi A, Nayanar V, Pagani G (1989) Mucolpidosis II: correlation between radiological features and histopathology of the bones. Pediatr Radiol 19: 406-413

24. Pazzaglia UE, Beluffi G, Castello A, Coci A, Zatti G (1992) Bone changes of mucolipidosis II at different ages. Clin Orthop 276: 283-290

25. Pollak MR, Brown EM, Chou YH, Hebert SC, Marx SJ, Steinmann B, Levi T, Seidman CE, Seidman JG (1993) Mutations in human calcium-sensing receptor gene cause familial hypocalciuric hypercalcemia and neonatal severe hyperparathyroidism. Cell 75: 1297-1303

26. Rapola J, Aula P (1977) Morphology of the placenta in fetal I-cell disease. Clin Genet 11: 107-113

27. Reitman ML, Kornfeld S (1981) Lysosomal enzyme targeting. $\mathrm{N}$-acetylglucosaminylphosphotransferase selectively phospho- rylates native lysosomal enzymes. J Biol Chem 256: 1197711980

28. Salle BL, Delvin EE, Lapillonne A, Bishop NJ, Glorieux FH (2000) Perinatal metabolism of vitamin D. Am J Clin Nutr 71[Suppl]:1317S-1324S

29. Saul R, Proud V, Taylor H, Leroy J, Spranger J (2004) Pacman dysplasia is a prenatal form of mucolipidosis type II (I-cell disease). Am J Hum Genet 75[Suppl]: 652

30. Shohat M, Rimoin DL, Gruber HE, Lachman RS (1993) New epiphyseal stippling syndrome with osteoclastic hyperplasia. Am J Med Genet 45: 558-561

31. Sprigz RA, Doughty RA, Spackman TJ, Murane MJ, Coates PM, Koldovsky O, Zackai EH (1978) Neonatal presentation of I-cell disease. J Pediatr 93: 954-958

32. Whelan DT, Chang PL, Cockshott PW (1983) Mucolipidosis II. The clinical, radiological and biochemical features in three cases. Clin Genet 24: 90-96

33. Wilcox WR, Lucas BC, Loebel B, Bachman RP, Lachman RS, Rimoin DL (1998) Pacman dysplasia: report of two affected sibs. Am J Med Genet 77: 272-276

34. Yashiro N, Abe T (1985) Radiological features of neonatal mucolipidosis II (I-cell disease): a case report. Radiat Med 3: 95-98 